\title{
Screening of TnphoA mutants of Vibrio cholerae 0139 for identification of antigens involved in colonisation
}

\author{
V. P. BONDRE, R. SRIVASTAVA, V. B. SINHA and B. S. SRIVASTAVA \\ Division of Microbiology, Central Drug Research Institute, Lucknow 226001, India
}

\begin{abstract}
A new serogroup of Vibrio cholerae non-01, designated as 0139, has emerged causing cholera-like disease among adults. Laboratory and field studies clearly show that there is no cross-protection between 01 and 0139 pathogenic strains. Since colonisation of the intestine is a most important step in the pathogenesis of cholera caused by 01 strains and colonising antigens are known to be protective, investigation of the colonising antigens of 0139 strain was initiated. By TnphoA mutagenesis, mutants were generated with insertions in the genome encoding membrane spanning or secretory proteins. Screening of the mutants for adherence to rabbit intestinal surface and colonisation in 5-day-old mice resulted in the identification of mutant clones, which were less adhesive than was the wild-type parent strain and which could not efficiently colonise the gut. Such non-colonising strains were attenuated in virulence. Analysis of the proteins by SDS-PAGE revealed that the non-colonising mutants did not express a 40-kDa outermembrane protein.
\end{abstract}

\section{Introduction}

In late 1992, a cholera-like disease caused by a new non-O1 organism designated as Vibrio cholerae 0139 spread across India, Bangladesh [1, 2] and Thailand [3]. The disease caused by O139 strains was reported to be indistinguishable from cholera in clinical features and response to treatment [4]. As most of the affected patients were adults who were not primed previously with the 0139 serogroup and prior exposure to $V$. cholerae $\mathrm{O} 1$ gave no cross-protection, it may be argued that the 0139 strains differ from $\mathrm{O} 1$ strains in critical antigens involved in protection and the vaccine being developed against $V$. cholerae $\mathrm{O} 1$ is not likely to be effective against $V$. cholerae O139. Hence, the virulence factors of serogroup O139 will have to be investigated before formulating strategies to develop vaccine for the control of cholera caused by 0139 strains.

Studies on the pathogenesis of $V$. cholerae $\mathrm{O} 1$ suggest that adherence of vibrios to the mucosal cell surface is an important step leading to the colonisation and subsequent production of the cholera toxin that causes

Received 4 Feb. 1997; revised version accepted 23 April 1997.

Corresponding author: Dr B. S. Srivastava. diarrhoea $[5,6]$. It is also known that the antigens involved in colonisation induced protection in experimental cholera [7-9]. Therefore, the colonising antigens of the serogroup $\mathrm{O} 139$ were investigated. A panel of mutants was generated by Tn phoA mutagenesis and screened to identify the adhesive and colonising antigens of $V$. cholerae 0139.

\section{Materials and methods}

\section{Bacteria and media}

Bacteria, plasmids and $\mathrm{Tn}$ phoA mutants are described in Table 1. The rifampicin-resistant spontaneous

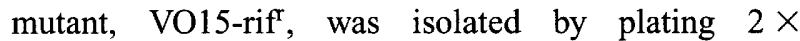
$10^{8}$ cells of strain VO15 on L-agar plates containing rifampicin $100 \mu \mathrm{g} / \mathrm{ml}$. Nutrient broth and L-broth (Difco) were routinely used for growing the bacteria and were prepared according to the manufacturer's instructions. Plates were prepared by adding Difco agar $1.2 \%$. L-broth, brain heart infusion broth $(\mathrm{BHI})$ and casamino yeast extract broth (CYE) have been described previously [10]. Bacterial dilutions were made in phosphate-buffered saline (PBS), $\mathrm{pH} 7.3$ [11]. Membrane-filtered solutions of tetracycline (12 mg/L), kanamycin $(45 \mathrm{mg} / \mathrm{L})$, gentamicin $(30 \mathrm{mg} / \mathrm{L})$, rifampicin $(50 \mathrm{mg} / \mathrm{L})$ and 5-bromo,4chloro,3-indolylphosphate (BCIP, $40 \mathrm{mg} / \mathrm{L}$ ) were added to the sterilised medium. 


\section{Construction of TnphoA mutants}

Random insertion of Tn phoA into the VO15 chromosome was accomplished by plasmid pRT291, a derivative of pRK290, that carries a copy of TnphoA $[12,13]$. The plasmid was transferred by conjugation to mutant VO15-rif ${ }^{\mathrm{T}}$ and transposition was allowed to occur at $37^{\circ} \mathrm{C}$ for $18 \mathrm{~h}$. Chromosomal inserts of TnphoA were obtained by conjugal transfer of incompatible plasmid pPH1JI and simultaneous selection for kanamycin and gentamicin resistance, which allowed selection of pPH1JI, retention of $\operatorname{Tn} p h o \mathrm{~A}$ and elimination of pRT291. As TnphoA was transposed from pRT291 to the chromosome, all colonies were rifampicin-, kanamycin- and gentamicin-resistant, and susceptible to tetracycline. VO15 isolates carrying TnphoA inserts were screened for by alkaline phosphatase activity on L-agar containing glucose $0.2 \%$ and $\mathrm{BCIP}$, at $37^{\circ} \mathrm{C}$. Transposon insertions that resulted in the production of fusion proteins directed by signal sequences were detected as blue colonies.

\section{Southern analysis}

A $2.65-\mathrm{kb} B g l \mathrm{II}$ fragment containing the kanamycin resistance gene of Tn phoA served as the DNA probe for hybridisation. The probe was labelled with digoxigenin (Boehringer Mannheim Biochemicals) according to the manufacturer's protocol. Briefly, total DNA was extracted from VO15 and TnphoA mutants by SDS lysis, phenol-chloroform extraction and ethanol precipitation. DNA was digested overnight with restriction endonuclease EcoRV, which does not recognise sequences present within $\mathrm{Tn} p h o \mathrm{~A}$, and separated by electrophoresis in agarose $0.8 \%$. Southern hybridisation was performed as described previously [10].

\section{Adherence}

Adherence of VO15 and TnphoA mutants to freshly isolated rabbit intestinal discs was measured as described previously [9]. The adherence index is the number of adherent vibrios expressed as a percentage of the total number of vibrios to which the disc of intact rabbit intestinal mucosa was exposed.

\section{Colonisation}

Intestinal colonisation of the vibrios was measured in 5 -day-old mice by oral infection with a single strain [9, 11]. Infant mice were fed with $\left(5 \times 10^{5}\right)-10^{6}$ vibrios in $0.1 \mathrm{ml}$ of PBS containing Evan's blue dye. Viable counts of vibrios in the intestine were made after 48 and $72 \mathrm{~h}$. The intestine was dissected out and homogenised in PBS. After suitable dilutions, samples were plated on nutrient agar plates containing rifampicin for VO15 and kanamycin for TnphoA mutants. To measure the effect of antibodies, vibrios were opsonised with a sub-agglutinating concentration of antibodies, given orally, and the survival of opsonised vibrios in intestine was measured after $24 \mathrm{~h}$ as described previously [9].

\section{Virulence}

The virulence of VO15 and TnphoA mutant strains was measured in 5-day-old mice. Bacterial dilutions containing $10^{7}$ cells were inoculated orally and mortality was observed up to $72 \mathrm{~h}$.

\section{SDS-PAGE}

Cells from a fresh culture were collected and suspended in Tris-Cl buffer (10 mM, pH 8.0). Total protein was estimated with the Folin phenol reagent [14] and analysed on polyacrylamide $4 \% \mathrm{v} / \mathrm{v}$ stacking and $12 \% \mathrm{v} / \mathrm{v}$ separation gels. The sample buffer contained SDS $1 \%$. Proteins to be analysed were mixed with sample buffer $[9,15]$ and kept in a boiling water bath for $5 \mathrm{~min}$ before being loaded on to the gel. Gels were stained with Coomassie Blue $0.1 \%$ and destained in acetic acid $10 \% \mathrm{v} / \mathrm{v}$ and methanol $20 \%$ $\mathrm{v} / \mathrm{v}$.

\section{Immunisation and protection}

Swiss albino rabbits weighing $1 \mathrm{~kg}$ were immunised subcutaneously with two injections ( $50 \mu \mathrm{g}$ each dose) of $40-\mathrm{kDa}$ protein and challenged with $10^{4}$ cells of VO15 in the ileal loop model as described previously [9]. The $40-\mathrm{kDa}$ antigen was obtained by separating the total proteins of VO15 by SDS-PAGE. The $40-\mathrm{kDa}$ protein band was cut out and electroeluted [15]. After dialysis with several changes of Tris-Cl buffer at $4^{\circ} \mathrm{C}$, the protein was ready to be used as an immunising agent.

\section{Results}

\section{TnphoA mutants}

Several epidemic strains of $V$. cholerae $\mathrm{O} 139$ isolated from different parts of India were analysed and found to be identical in adherence and colonisation characteristics. The total protein profile in SDS-PAGE was also identical. Hence, one of the strains, VO15, was selected for investigation. Tn phoA mutagenesis of strain VO15 was designed to effect mutations in secretory or membrane spanning proteins; mutants that had in-frame insertions of TnphoA and produced fusion proteins were detected as blue colonies on BCIP plates. About $2 \%$ of colonies carrying Tn phoA inserts were blue. Sixty-three blue colonies were picked and purified by streaking on BCIP plates. Southern analysis of total DNA of several randomly chosen blue colonies digested with EcoRV revealed that the mutants described in Table 1 contained a single TnphoA insertion in the genome (Southern blot not shown).

\section{Adherence of TnphoA mutants}

All the 63 mutants were screened for their adherence to freshly isolated rabbit intestinal discs. Three mutants (M-14, M-19 and M-32) were less adhesive than the parent strain VO15 (Table 1). These least adhesive 
Table 1. Bacterial strains, plasmids and indices of adherence and colonisation, virulence

\begin{tabular}{|c|c|c|c|c|}
\hline \multirow{2}{*}{$\begin{array}{l}\text { Bacteria with } \\
\text { relevant markers }\end{array}$} & \multirow{2}{*}{$\begin{array}{l}\text { Adherence } \\
\text { index* }\end{array}$} & \multicolumn{2}{|c|}{ Colonisation index ${ }^{\dagger}$} & \multirow[b]{2}{*}{ Virulence } \\
\hline & & $48 \mathrm{~h}$ & $72 \mathrm{~h}$ & \\
\hline \multicolumn{5}{|l|}{ V. cholerae $\mathrm{O}^{\S}$} \\
\hline KB207, wild-type El Tor & 1.9 & $10^{2}$ & ND & ND \\
\hline $\begin{array}{l}\text { CD11, non-adhesive mutant } \\
V \text {. cholerae } 0139\end{array}$ & 0.02 & $<1$ & ND & ND \\
\hline VO15, wild type & 5.4 & $7.0 \times 10^{3}$ & ND & $6 / 6$ \\
\hline $\begin{array}{l}\text { VO15-rif } \text {, rifampicin-resistant } \\
\text { spontaneous mutant of VO15 }\end{array}$ & 5.0 & $3.3 \times 10^{3}$ & ND & $6 / 6$ \\
\hline $\mathrm{M}-14, \operatorname{Tn} p h o \mathrm{~A}$ mutant of VO15-rif & 0.95 & 2.0 & 3.6 & $1 / 6$ \\
\hline M-19, TnphoA mutant of VO15 rif & 0.33 & 1.6 & 0.6 & $0 / 6$ \\
\hline $\begin{array}{l}\text { M-32, Tn phoA mutant of VO15 } \text { rif }^{\mathrm{r}} \\
\text { E. colil } \\
\text { SM10 (pRT291), } \\
\text { Tn phoA, Km }{ }^{\mathrm{r}}, \mathrm{Tc}^{\mathrm{r}} \\
\text { MM294 (pPH1JI), Gm }\end{array}$ & 0.86 & 1.4 & 5.6 & $1 / 6$ \\
\hline
\end{tabular}

ND, not determined.

*The number of vibrios adherent to the intestinal disc as a percentage of the total number of

vibrios to which it was exposed.

${ }^{\dagger}$ Increase in viable counts of vibrios over viable counts of the inoculum.

${ }^{\ddagger}$ Number of deaths over the number of mice inoculated.

${ }^{\S}$ Strains described in Jacob et al. [9].

"Plasmids described by Singh et al. [10].

mutants were selected to examine intestinal colonisation.

\section{Colonisation of the TnphoA mutants}

The less adhesive mutants did not colonise the intestine as efficiently as the parent strain. The parent strain VO15 persisted in the gut in high numbers. The viable counts increased 20-100-fold in $24 \mathrm{~h}$. The viable count of the three mutants was several fold less and the colonisation index was very low (Table 1). When strain VO15 was opsonised with rabbit anti-VO15 antibodies, a decrease in viable counts was observed (Table 2), suggesting a role for cell surface antigens in colonisation and its inhibition by antibodies.

\section{Virulence of TnphoA mutants}

Virulent strains of $V$. cholerae $\mathrm{O} 1$ are lethal in infant mice as a consequence of colonisation of intestine and the ensuing disease. Hence, the virulence of noncolonising mutants was determined in an infant mouse model and deaths were observed up to $72 \mathrm{~h}$ and compared with deaths in uninfected control mice and in

Table 2. Inhibition of intestinal colonisation of VO15 by anti-VO15 and anti-40-kDa sera in infant mice

\begin{tabular}{lc}
\hline $\begin{array}{l}\text { Incubation medium (for } 30 \mathrm{~min} \\
\text { pre-injection) }\end{array}$ & $\begin{array}{c}\text { Viable count in intestine at } \\
24 \mathrm{~h}(\mathrm{cfu})\end{array}$ \\
\hline PBS & $2.4 \times 10^{8}$ \\
PBS + normal serum & $1.3 \times 10^{8}$ \\
PBS + anti-VO15 serum & $1.2 \times 10^{5}$ \\
PBS + anti-40-kDa serum & $1.9 \times 10^{6}$ \\
\hline
\end{tabular}

Before oral administration to infant mice, $1.2 \times 10^{6}$ bacteria were incubated at room temperature in PBS or PBS with 10 -fold dilutions of the lowest agglutinating titre of the respective serum; $0.1 \mathrm{ml}$ was fed orally to each mouse. mice infected with the parent strain VO15. Whereas all the mice infected with VO15 died, the non-colonising mutants were attenuated in virulence (Table 1).

\section{Analysis of proteins}

Strain VO15 and non-colonising mutants were analysed by SDS-PAGE. The total protein profile showed that the mutants do not express a major outer-membrane protein of $40 \mathrm{kDa}$ (Fig. 1). The expression of the 40$\mathrm{kDa}$ protein was examined in different media such as nutrient broth, CYE and $\mathrm{BHI}$, and in different incubation conditions such as growth at $28^{\circ} \mathrm{C}$ and $37^{\circ} \mathrm{C}$ with and without aeration. In the parent strain VO15, the $40-\mathrm{kDa}$ protein was enriched in the outermembrane fraction (data not shown) and was observed irrespective of media composition and growth conditions, whereas the mutants lacked this protein (Fig. 1). This suggested that the integration of TnphoA may have occurred in the structural gene.

\section{Protection}

Protection against challenge with strain VO15 in rabbits immunised with $40-\mathrm{kDa}$ protein is shown in Table 3. Control unimmunised rabbits showed no protection. The $40-\mathrm{kDa}$ antigen did not provide good protection but the degree of protection was similar to that given by membrane preparation of VO15.

\section{Discussion}

An apparent lack of cross-protection between $V$. cholerae serogroups $\mathrm{O} 1$ and $\mathrm{O} 139[16,17]$ means that serogroup $\mathrm{O} 139$ has different somatic and other protein antigens that are critical for protection. They need to 

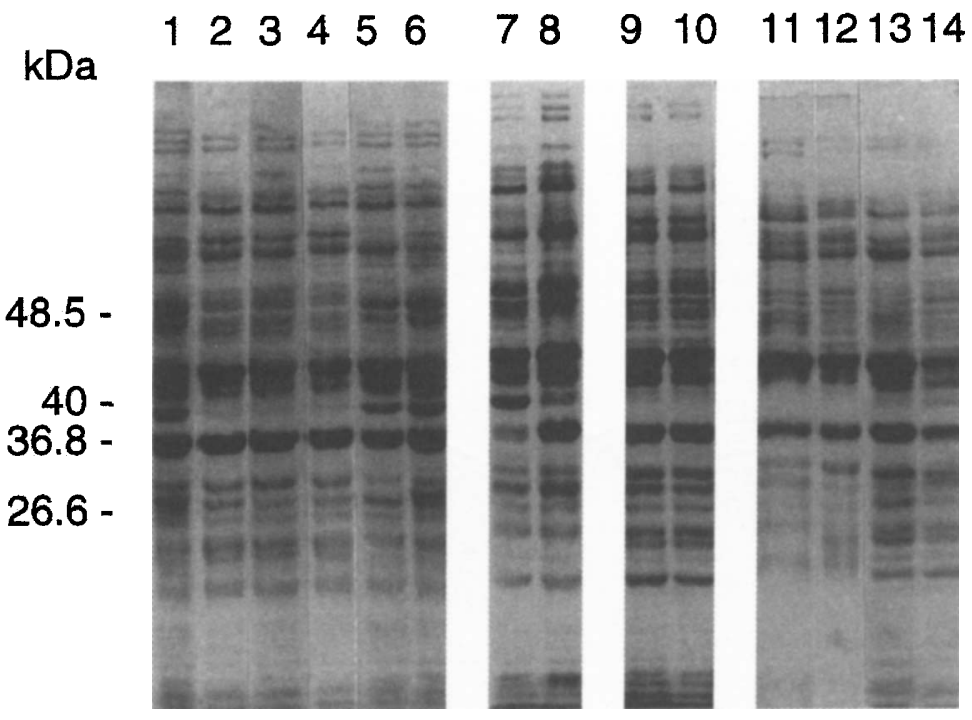

Fig. 1. SDS-PAGE profile of the total proteins of VO15 (lane 1), M-14, M-19 and M-32 (2-4), two TnphoA colonising mutants $(\mathbf{5}, \mathbf{6})$; VO15 grown in CYE (7), BHI (8); M-14 grown in CYE (9), BHI (10); M-19 grown in CYE (11), BHI (12); M-32 grown in CYE (13), BHI (14). Pre-stained protein mol.wt markers (Sigma) of 48.5, 36.8 and $26.6 \mathrm{kDa}$ and the $40-\mathrm{kDa}$ protein are indicated.

Table 3. Protection provided by $40-\mathrm{kDa}$ antigen and membrane proteins in rabbit intestinal experiments in which the rabbits were immunised subcutaneously and the challenge strain was VO15

\begin{tabular}{lc}
\hline Vaccine & Protection (\%) \\
\hline Control & 0 \\
$40-\mathrm{kDa}$ antigen & 37 \\
Membrane proteins & 45 \\
\hline
\end{tabular}

be investigated to develop a vaccine against serogroup O139. Previous experiments with $V$. cholerae $\mathrm{O} 1$ suggest clearly that the colonising antigens of $\mathrm{O} 1$ strains provide significant protection in experimental cholera [7-10]. Antigens of O139 strains involved in colonisation have not been identified so far. The toxin co-regulated fimbria, an essential colonisation factor of $V$. cholerae $\mathrm{O} 1$, has been found in all strains of $\mathrm{O} 139$ [18]. Similarly, fimbriae common to $\mathrm{O} 1$ and non-O1 strains were found to be present among many strains of O139; but all these studies are rather inconclusive regarding their role in colonisation by $\mathrm{O} 139$ strains.

In the past few years, $\mathrm{Tn}$ phoA insertion mutagenesis has been used successfully to characterise genes encoding cell surface and membrane spanning proteins of $V$. cholerae $[10,13,19]$. With the same strategy, a panel of mutants was isolated in which the integration of transposon occurred in-frame in genes encoding cell surface or membrane spanning proteins. When analysed for colonisation, three mutants were identified which did not colonise the gut of the infant mouse as efficiently as did the parent strain VO15. The mutants lacked a protein of c. $40-\mathrm{kDa}$, which is a major outer-membrane protein. Membrane proteins of 0139 strains in the same molecular range have been reported previously $[20,21]$.
That the $40-\mathrm{kDa}$ protein has a role in colonisation and pathogenesis is evident because a single transposon insertion caused loss of expression of this protein associated with reduced colonisation and attenuation of virulence. The purified protein recovered from SDS-PAGE induced protection which was not significant but strikingly identical to the protection given by the membrane protein fraction of strain V015. Perhaps it might be possible to achieve higher levels of protection by modifications in the dose of the antigen and schedule of immunisation. While the colonising factors of $V$. cholerae $\mathrm{O} 1$ play a significant role in protection, the colonising antigen of $\mathrm{O} 139$ identified in this work is less effective. Are there other antigens that contribute synergically in colonisation and protection? Unpublished data generated in this laboratory strongly suggest this possibility and that the role of a polysaccharide capsule covering the O139 strains but absent in $\mathrm{Ol}$ strains may be important in protection. A good correlation has been found between colonisation and protection in passive immunisation experiments with antibodies to the polysaccharide capsule [22]. Therefore, 0139 strains need to be extensively investigated to identify relevant antigens, determine their virulence and to develop strategies for immunoprophylaxis.

We are grateful to the Director of the Institute for interest and support. V.P.B. was supported by a Senior Research Fellowship of C.S.I.R. India. This work was supported by a grant from the Department of Biotechnology, Government of India to B.S.S. We are grateful to Dr G. B. Nair for the gift of clinical isolates of $V$. cholerae O139 strains. (Communication no. 5610 of CDRI.)

\section{References}

1. Shimada T, Nair GB, Deb BC, Albert MJ, Sack RB, Takeda Y. Outbreak of Vibrio cholerae non-O1 in India and Bangladesh. 
Lancet 1993; 341: 1346-1347.

2. Cholera Working Group. International Centre for Diarrhoeal Diseases Research, Bangladesh. Large epidemic of cholera-like disease in Bangladesh caused by Vibrio cholerae 0139 synonym Bengal. Lancet 1993; 342: 387-390.

3. Chongsa-nguan $\mathrm{M}$, Chaicumpa W, Moolasart $\mathrm{P}$ et al. Vibrio cholerae O139 in Bangkok. Lancet 1993; 342: 430-431.

4. Bhattacharya SK, Bhattacharya MK, Nair GB et al. Clinical profile of acute diarrhea cases infected with the new epidemic strain of Vibrio cholerae O139: designation of the disease as cholera. J Infect 1993; 27: 11-15.

5. Nelson ET, Clements JD, Finkelstein RA. Vibrio cholerae adherence and colonization in experimental cholera: electron microscopic studies. Infect Immun 1976; 14: 527-547.

6. Srivastava R, Sinha VB, Srivastava BS. Events in the pathogenesis of experimental cholera: role of bacterial adherence and multiplication. J Med Microbiol 1980; 13:1-9.

7. Sharma DP, Thomas C, Hall RH, Levin MM, Attridge SR Significance of toxin-coregulated pili as protective antigens of Vibrio cholerae in the infant mouse model. Vaccine 1989; 7 : 451-456.

8. Sun D, Mekalanos JJ, Taylor RK. Antibodies directed against the toxin-coregulated pilus isolated from Vibrio cholerae provide protection in the infant mouse experimental cholera model. J Infect Dis 1990; 161: 1231-1236.

9. Jacob A, Sinha VB, Sahib MK, Srivastava R, Kaper JB, Srivastava BS. Identification of a $33 \mathrm{kDa}$ antigen associated with an adhesive and colonizing strain of Vibrio cholerae $\mathrm{El}$ Tor and its role in protection. Vaccine 1993; 11: 376-382.

10. Singh SN, Srivastava R, Sinha VB, Srivastava BS. A $53 \mathrm{kDa}$ protein of Vibrio cholerae classical strain O395 involved in intestinal colonization. Microb Pathog 1994; 17: 69-78.

11. Kumar KK, Srivastava R, Sinha VB, Michalski J, Kaper JB, Srivastava BS. recA mutations reduce adherence and colonization by classical and $\mathrm{El}$ Tor strain of Vibrio cholerae. Microbiology 1994; 140: 1217-1222.

12. Manoil C, Beckwith J. TnphoA: a transposon probe for export signals. Proc Natl Acad Sci USA 1985; 82: 8129-8133.

13. Taylor RK, Miller VL, Furlong DB, Mekalanos JJ. The use of phoA gene fusions to identify a pilus colonization factor coordinately regulated with cholera toxin. Proc Natl Acad Sci USA 1987; 84: 2833-2837.

14. Lowry $\mathrm{OH}$, Rosebrough $\mathrm{NJ}$, Farr AL, Randall RJ. Protein measurement with the Folin phenol reagent. $J$ Biol Chem 1951; 193: $265-275$

15. Hames BD. An introduction to polyacrylamide gel electrophoresis. In: Hames BD, Rickwood D (eds) Gel electrophoresis of proteins: a practical approach. London, IRL Press. 1981: 186.

16. Albert MJ, Alam K, Ansaruzzaman M, Qadri F, Sack RB. Lack of cross-protection against diarrhea due to Vibrio cholerae O139 (Bengal strain) after oral immunization of rabbits with Vibrio cholerae O1 vaccine strain CVD103-HgR. $J$ Infect Dis 1994; 169: 230-231.

17. Takeda T, Ramamurthy $\mathrm{T}$, Chowdhury AS et al. Vibrio cholerae $\mathrm{O} 1$ vibriocidal and anti-cholera toxin antibodies in O139 Bengal cholera patients. $J$ Infect 1994; 29: 233-235.

18. Waldor MK, Mekalanos JJ. ToxR regulates virulence gene expression in non-O1 strains of Vibrio cholerae that cause epidemic cholera. Infect Immun 1994; 62: 72-78.

19. Comstock LE, Maneval D, Panigrahi $\mathrm{P}$ et al. The capsule and $\mathrm{O}$ antigen in Vibrio cholerae $\mathrm{O} 139$ Bengal are associated with a genetic region not present in Vibrio cholerae $\mathrm{O} 1$. Infect Immun 1995; 63: 317-323.

20. Calia KE, Murtagh M, Ferraro MJ, Calderwood SB. Comparison of Vibrio cholerae $\mathrm{O} 139$ with $V$. cholerae $\mathrm{O} 1$ classical and El Tor biotypes. Infect Immun 1994; 62: 1504-1506.

21. Nandy RK, Sengupta TK, Mukhopadhyay S, Ghose AC. A comparative study of the properties of Vibrio cholerae $\mathrm{O} 139$, $\mathrm{O} 1$ and other non-O1 strains. $J$ Med Microbiol 1995; 42: $251-257$

22. Sengupta DK, Boesman-Finkelstein M, Finkelstein RA. Antibody against the capsule of Vibrio cholerae 0139 protects against experimental challenge. Infect Immun 1996; 64: 343-345. 